\title{
電界共役流体を用いた ポンプ・タンクー体型液圧駆動ロボットフィンガ*
}

\author{
山口彰 浩*1, 竹村 研治郎*2 \\ 横 田 穓 一*3, 枝 村 一 弥*4
}

\section{A Robot Finger with Integrated Pump/Tank Using Electro-Conjugate Fluid}

\author{
Akihiro YAMAGUCHI ${ }^{* 5}$, Kenjiro TAKEMURA, \\ Shinichi YOKOTA and Kazuya EDAMURA \\ ${ }^{* 5}$ Department of Mechanical Engineering, Keio University, \\ 3-14-1 Hiyoshi, Kouhoku-ku, Yokohama-shi, Kanagawa, 223-8522 Japan
}

\begin{abstract}
Electro-conjugate fluid (ECF) is a kind of functional fluid, which produces a jet flow (ECF jet) when subjected to high DC voltage. It is known that a strong ECF jet is generated under nonuniform electric field, for example, the field with a pair of needle and ring electrode. This study introduces the ECF jet to develop a novel robot finger. First, we propose a concept of the robot finger which mainly consists of an ECF jet generator, a bending actuator and an ECF tank. The robot finger is driven by ECF jet, and integrated with a pump and a tank. Next, we characterize the ECF jet generator and confirm the effect of the variation of electrode gap and number of electrode pair on its performance. Finally, we investigate the characteristics of the robot finger. The length, the diameter, and the mass of the robot finger are $25 \mathrm{~mm}, 5 \mathrm{~mm}$, and $3.8 \mathrm{~g}$, respectively. The robot finger can move $27.8 \mathrm{~mm}$ in $x$ direction and $26.7 \mathrm{~mm}$ in $y$ direction at $3.1 \mathrm{~s}$ when ECF jet generator is applied at 6.0 $\mathrm{kV}$.
\end{abstract}

Key Words: Functional Fluid, Robot Hand, Actuator, Micro-Mechanism, Electro-Conjugate Fluid, Soft Actuator, Robot Finger

\section{1. 緒言}

近年のロボット技術の進歩により, ロボットの活躍 の場は従来の規格化された工場内から街や家庭といっ た人の生活空間へと拡大しつつあり，人との接触を前 提としたロボットハンドの開発が数多く行われてい る(1)(2).これらのロボットハンドは, 小型化, 軽量化 および柔軟化が安全性向上といった観点から重要な課 題となる.しかし，従来研究に打いて開発されてきた ロボットハンドの多くは，小型化，軽量化执よび柔軟 化という点に関しては十分であるといえない。この原 因として, 多くのロボットハンドは駆動源にサーボモ ータを用いていることが挙げられる(3).サーボモータ は，高度な位置決め制御が可能であり，応答性および

* 原稿受付 2010 年 6 月 10 日.

*1 学生員, 慶應義塾大学大学院理工学部研究科総合デザイン工 学専攻 (画 223-8522 横浜市港北区日吉 3-14-1).

*2 正員, 慶應義塾大学機械工学科.

*3 正員, フェロー, 東京工業大学精密工学研究科(ङ226-8503 横浜市緑区長津田町 4529-R2-41).

*4 正員, (有) 新技術マネイジメント(昰124-0023 東京都葛飾 区東新小岩 2-9-1-306).

E-mail : b_1_h_1987@yahoo.co.jp
安定性に優れているが，自由度の増加に伴いアクチュ エータが増加するため, 小型化扔よび軽量化が困難で ある(4). 近年では，サーボモータと比較して小型化扔 よび軽量化に有利であるとされている超音波モー夕を 用いたロボットハンドも開発されている(5). しかし， 超音波モー夕自体に柔軟性が無いため, 超音波モータ を用いてロボットハンドの柔軌化を行うには複雑な制 御が必要となる。これらの問題への解決策として, 空 気圧ソフトアクチュエータに代表されるような流体恠 駆動のアクチュエータに関する研究が盛んに行われて いる(6)(7)，流体圧駆動アクチュエー夕は，ゴムなどの 柔軟材を用いてアクチュエータを構成することによ り，アクチュエータ自体の柔軟化が可能である。しか し，流体圧駆動アクチュエータの多くは，ポンプ，夕 ンクおよびバルブなどといった周辺機器が必要とな

る。このため, 装置全体としては大型化する。

このような背景から, 本研究では電界共役流体 (Electro-conjugate fluid, ECF) に着目した. ECF と は，液中に挿入された電極対に直流高電圧を印加する ことにより活発な流動(ECF ジェット)を発生する機 能性流体である。 ECF は, 微小化特性に優れ, ECF 
ジェット発生に必要な電極対の構造が単純であること から小型化および軽量化に適した液圧駆動源であると 言える(8). また, 電圧の印加のみによって流動の発生 を制御できるため，ポンプおよびタンクといった周辺 機器を外部に必要としない(9).このため, ECFを駆動 源として用いることにより，ポンプおよびタンクを一 体化した液圧駆動アクチュエータの実現が可能である と考えられる。

以上の背景に鑑み, 本研究では, 小型軽量かつ柔軟 なロボットハンドの実現を目指し，アクチュエータ， ポンプおよびタンクが一体となったロボットフィンガ の開発を目的とする。

\section{2. 電界共役流体}

$\mathrm{ECF}$ とは，ある種の誘電性液体であり，液中に挿入 した電極対に直流高電圧を印加することによって，活 発な流動(ECF ジェット)を発生する機能性流体であ る. ECF 内に不均一な電界が生じた際に流動が発生 し，この流動効果は ECF 効果と呼ばれている。流動 を発生させるためには，たとえば，図 1 に示すような 1 組の針状-リング状電極対が必要である。図 1 に示 したように 1 組の電極対によって一方向に流動が発生 し，流動の方向は，針状電極からリング状電極に向か う方向である(8).

\section{3. ポンプ・タンク一体型液圧駆動 ロボットフィンガの提案}

提案するロボットフィンガを図 2 ( a ) に示す。ロボ ットフィンガは，湾曲アクチュエータ，ECF ジェット

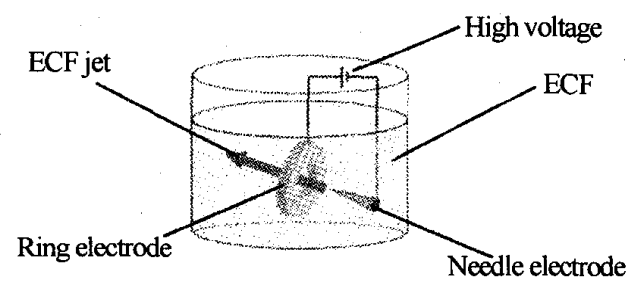

Fig. 1 Schematic diagram of ECF jet

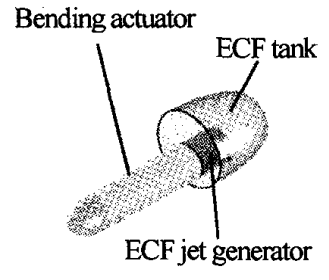

(a) Configuration

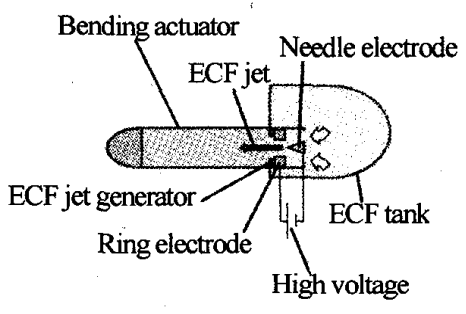

(b) Inner construction
Fig. 2 Concept of robot finger
発生部扔よび ECF タンクによって構成され，内部は $\mathrm{ECF}$ にり満たされている. ECFタンクはシリコー ンゴム製であり，アクチュエータは，図 3 に示すよう に円筒状のシリコーンゴムチューブと周囲に配置され た強化繊維によって構成される。ゴムチューブの周方 向に複数の強化繊維が等間隔に配置され，さらに，軸 方向に 1 本の強化瀻維が配置されている.ゴムチュー ブの内圧上昇によって発生する膨張は，周方向の繊維 拘束により半径方向の伸びが抑えられ，軸方向の伸び に変換される。しかし，軸方向に強化瀻維が配置され ている箇所では，軸方向の伸びが拘束される。このた め，ゴムチューブ内を加圧することによって図 4 に示 すようにアクチュエータは軸方向に配置された強化繊 維の側に大きく湾曲する。

図 2(b)に示すように, ECF タンク内部に配置され た ECF ジェット発生部に直流高電圧を印加すること により, ECFタンクからアクチュエータ内部へ ECF ジェットによる流動が発生する。このため, ECF ジ エットによりアクチュエータの内圧が上昇し，アクチ ユエータを湾曲させることが可能であると考えられ る。また, ECF ジェット発生部への電圧印加を停止 すると ECF ジェットによる加压は停止し，シリコー ンゴムの弾性力によってアクチュエータは元の形状を 回復する。

提案するロボットフィンガと類似した先行研究とし て，空気圧により駆動されるアクチュエータ(10) が挙 げられるが, 本ロボットフィンガは, 圧力源を内蔵し ポンプおよびタンクが一体となっている点, 圧力源の 構造が機械式ポンプ(コンプレッサ)に比べ非常に単純

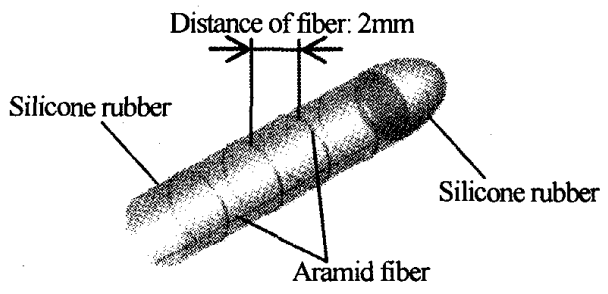

Fig. 3 Configuration of bending actuator

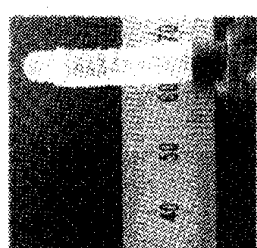

(a) Initial state

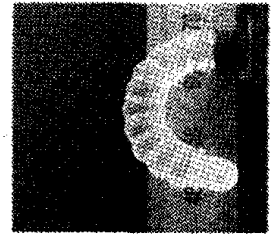

(b) Pressured at $60 \mathrm{kPa}$
Fig. 4 Motion of bending actuator 
である点および作動流体が内部に封入された閉じた系 である点に扔いて異なる。このような違いは，小型化 に执いて優位性を有すると考えられる。

なお，製作したアクチュエータの寸法は，全長 25 $\mathrm{mm}$, 直径 $5 \mathrm{~mm}$ であり, シリコーンゴムチューブの 膜厚は抢よそ $100 \mu \mathrm{m}$ である。

\section{ECF ジェット発生部}

4 ・1 設計および製作 ECF ジェット発生部を図 5 に示す. 図 5(a) は ECF ジェット発生部の構造を, 図 5(b) は組立て後の断面図を示している。図 5(a) に示すように, ECF ジェット発生部は, 外枠, カバー, スペーサ执よび電極対(リング状電極，針状電極扔よ びマウント)によって構成され，1つの ECF ジェット 発生部内に合計 $2 つ 0$ 電極対 (針状電極と穴の対) を有 する.図 5(b)に示すように, 針状電極はマウント中 心部の穴に差し込む形で接着されており，マウントと リング状電極の間にスペーサを挿入することにより電 極間隔を一定に保っている，なお，電極間隔とは，図 5(b)に示すように針状電極先端とリング状電極の間 隔のことである。また，外枠内部に入れられた電極対 およびスペーサは，両端のカバーによって固定されて いる.

Abe らの研究(8)により, 電極対寸法と ECF ジェッ トの流動には高い相関があることが明らかとなってお り，針状電極の直径，リング状電極の内径抢よび電極 間隔が $0.13 \mathrm{~mm}, 0.3 \mathrm{~mm}$ 抢よび $0.2 \mathrm{~mm}$ のとき比較 的強い流動が発生することが知られている。このた

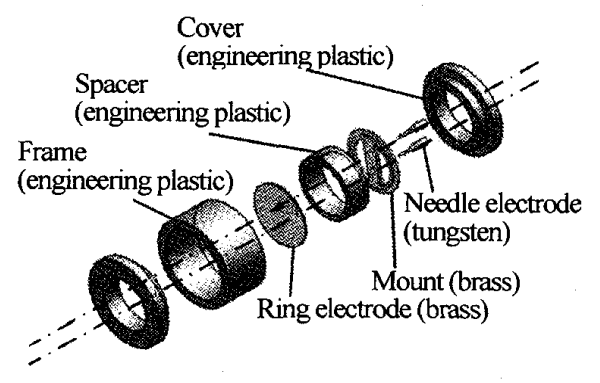

(a) Exploded view

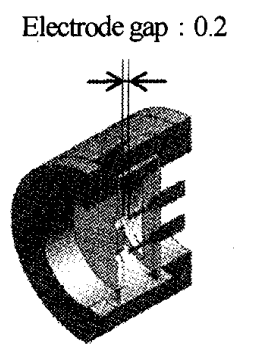

(b) Cross sectional view

Fig. 5 ECF jet generator
め, 本研究においても上記の電極寸法を採用した. な お, $\mathrm{ECF} シ ゙ ェ ッ ト$ 発生部全体の寸法は, 直径 $5.0 \mathrm{~mm}$, 全長 $3.4 \mathrm{~mm}$ である.

\section{$4 \cdot 2$ 実験}

$4 \cdot 2 \cdot 1$ 電極間隔/電極対数の変化による圧力/流量 の変化上述したように, 本研究では従来研究(8)を 参考とし電極間隔を $0.2 \mathrm{~mm}$ と設計した。また，文献 （８）における実験では，作動流体としてデカン二酸ジ ブチル (Dibutyl decane-dioate: DBD, 新技術マネイ ジメント社)を用いている。しかし，本研究において は, DBD と比較してより活発な流動を発生するとさ れている FF-101EHA2(新技術マネイジメント社)を 作動流体として用いた。このため, FF-101EHA2 用い, 各電極間隔を変化させた際の圧力特性および流 量特性を測定した。また，本研究においては，ECF ジ エット発生部内の電極対(針状電極と穴の対) 2 対と したため電極対数の変化による压力特性および流量特 性の測定も同様に行った。笑験結果を図 6 および図 7 に示す。なお, DBD 扔よび FF-101EHA2 の物性值は 表 1 に示す通りである。

まず，電極間隔および電極対数の変化による王力特 性への影響について述べる。図 6 より, 従来研究(8) と 同様に電極間隔を狭くするに従い発生圧力が増加して

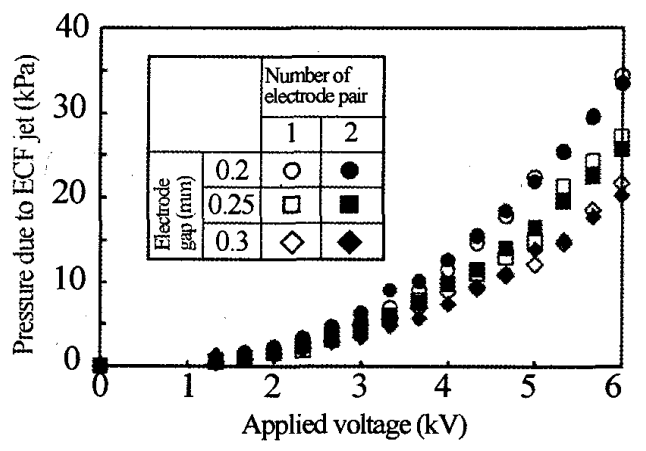

Fig. 6 Relationship between pressure and applied voltage

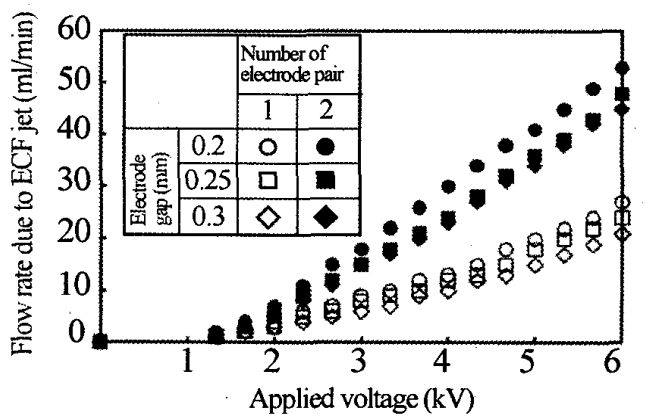

Fig. 7 Relationship between flow rate and applied voltage 
Table 1 Physical properties of DBD and FF-101EHA2

\begin{tabular}{l|c|c}
\hline \multicolumn{1}{c|}{ ECF } & DBD & FF-101EHA2 \\
Physical property & 4.6 & 7.2 \\
\hline Relative permittivity $[-]$ & $6.80 \mathrm{E}-10$ & $2.20 \mathrm{E}-07$ \\
\hline Electrical conductivity $[\mathrm{S} / \mathrm{m}]$ & 938 & 1540 \\
\hline Density $\left[\mathrm{kg} / \mathrm{m}^{3}\right]$ & 7.5 & 1.6 \\
\hline Viscosity $\left[\mathrm{mPa}^{2} \mathrm{~s}\right]$ & &
\end{tabular}

いることがわかる。なお，本実験結果は，DBDを作動 流体とした同条件の実験結果 ${ }^{(8)}$ と比較すると, 発生圧 力が約 5 倍となっている. 電極間隔を $0.2 \mathrm{~mm}$ 末満 とした際の測定も行ったが, $5.0 \mathrm{kV}$ 付近において電 極間に断続的な放電が生じたため電極間隔の最小值は $0.2 \mathrm{~mm}$ とした。一方，図 6 より電極対を 2 対とする ことにより，1 対の場合と比較し高電圧時に発生圧力 が僅かに減少する傾向にあることがわかる，これは， 2 つの電極対から発生する ECF ジェットの圧力に差

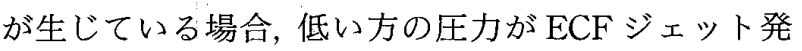
生部全体の発生圧力となるためであると考えられる.

つぎに，電極間隔および電極対数の変化による流量 特性への影響について述べる. 図 7 より, 電極対の数 にかかわらず，電極間隔を狭くするに従い流量が増加 していることが分かる。これより, 図 6 と合わせて考 えれば，電極間隔を狭くするに従い，より活発な流動 が発生していることがわかる。また，図 7 より電極対 数を 1 対から 2 対に増加することにより流量が約 2 倍 となることがわかる。

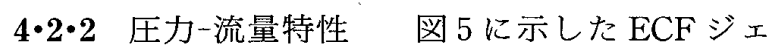
ット発生部 (電極対数 2 , 電極間隔 $0.2 \mathrm{~mm}$ ) に関して, 圧力と流量の関係を測定した. 測定結果を図 8 に示 す。なお，本実験では可変バルブを用いて流路内の負 荷圧力を調整することにより，各值を測定した。図 8 より, 製作したECF ジェット発生部の最大発生圧力 および最大発生流量は $6.0 \mathrm{kV}$ を印加した際に測定さ れた $33.55 \mathrm{kPa}$ 抢よび $53 \mathrm{ml} / \mathrm{min}$ であることがわか る.また, 流量と圧力の関係がほぼ線形となることを 確認した。

$4 \cdot 2 \cdot 3$ 電極対の直列配置による圧力/流量特性の変 化 図 5 に示したECF ジェット発生部を合計 $2 つ$ (Jet A, Jet B) 製作し, ECF ジェット発生部を直列配 置した際の圧力特性および流量特性を測定した，実験 結果を図 9 およ゙図 10 に示す。なお, 本実験では, Jet A の下流側に Jet B を配置し, この際, Jet A の針 状電極底面と Jet B のリング状電極の間隔は $1.4 \mathrm{~mm}$ とした.このとき, 逆方向 (Jet A から Jet B)への比 較的弱い流動が発生し, 順方向への流動に影響を与え

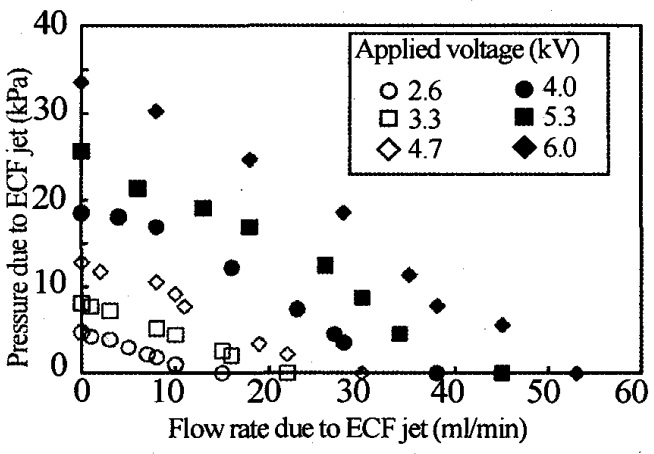

Fig. 8 Relationship between flow rate and pressure

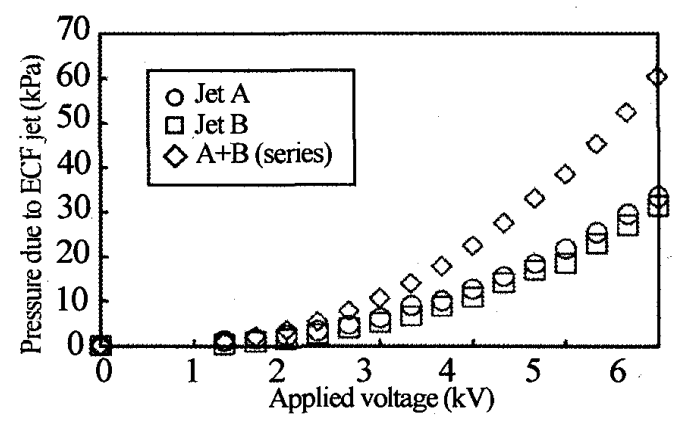

Fig. 9 Relationship between flow rate and applied voltage

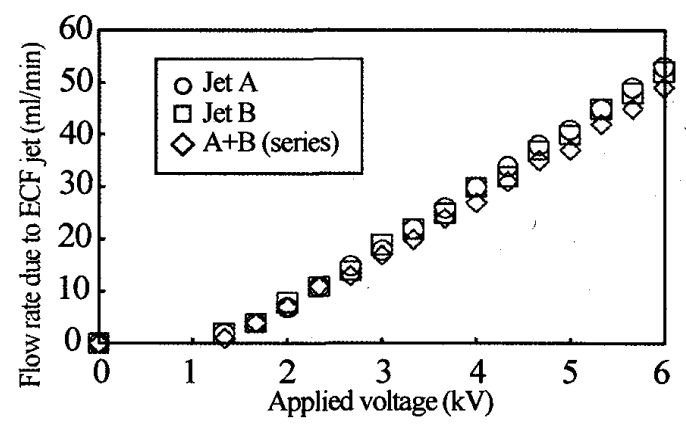

Fig. 10 Relationship between flow rate and applied voltage

ると考えられたため, 針状電極根元部分に絶縁コーテ イングを施した。

図 9 および図 10 より，製作した 2 つの ECF ジェッ 卜発生部は圧力および流量に関してほほ同等な特性を 示すことがわかる，また，これらの電極対を直列配置 すると圧力が約 2 倍となることを確認した. 本実験に おける最大発生圧力は $60.49 \mathrm{kPa}$ であり, これはアク チュエータの駆動に十分であることが図 4 よりわか る. 図 9 より電極対を直列配置した際の発生圧力は, Jet A および Jet B 単体における発生圧力を足し合わ せた值と比較し, 若干減少しているが,これは ECF ジェット発生部を直列配置したことによる流路内の抵 抗の増加に起因すると考えられる。また，図 10 より 2 
つの電極対を直列配置することにより，電極対単体の 場合と比較して流量が減少しているが, 減少量は最大 で $4 \mathrm{ml} / \mathrm{min}$ でありアクチュエータの駆動に大きな影 響はないと考えられる。

\section{ECF ジェットによる}

\section{湾曲アクチュエータの駆動実験}

$5 \cdot 1$ 実験 図 11 に示す実験装置を用いて ECF ジェットによる湾曲アクチュエータの駆動実験を行っ た。本実験は，ECF ジェットによるアクチュエータ の駆動が目的であるためアクチュエータ, ECFジェ ット発生部およびECF タンクを独立させ, それぞれ をゴムチューブを用いて接続した。また, ECFジェ ット発生部は上述の Jet A 扔よび Jet B を直列配置し たものを用いた。な抆，図11に扔いてアクチュエー 夕，ECF ジェット発生部捻よびゴムチューブの内部 は作動流体である FF-101EHA2により満たされてい る.ECFの充填に関しては, 真空引きを行うことに より達成した。すなわち, 図 11 に示す実験装置を真 空チャンバ内に配置し真空ポンプを用いて減圧した 後, チャンバ内に大気圧を導入することにより，アク チュエータ, ECF ジェット発生部扔よびゴムチュー ブ内部を ECFにより満たした。

$\mathrm{ECF} シ ゙ ェ ッ ト$ 発生部に $6.0 \mathrm{kV}$ を印加し $3.9 \mathrm{~s}$ 経過 した際の様子を図 12 に示す。なお, 初期状態は図 11 に示す状態である.また, 図11 および図 12 に示すよ うにアクチュエータ先端の初期位置に座標系を固定 し, 各印加電圧をステップ入力した際のアクチュエー

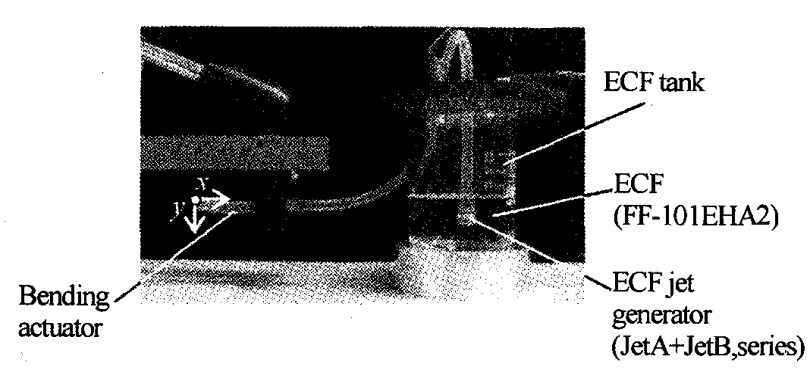

Fig. 11 Experimental setup

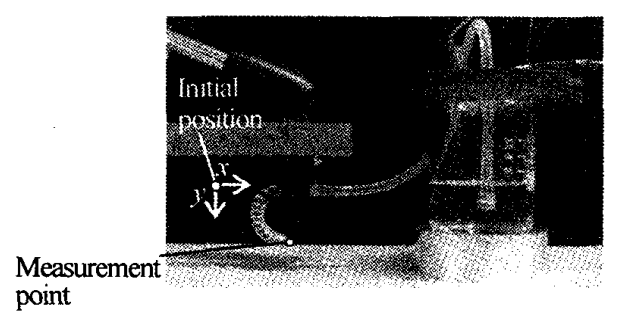

Fig. 12 Motion of the bending actuator (Applied voltage $6.0 \mathrm{kV}, t=3.9 \mathrm{~s}$ )
夕先端の変位を測定したところ図 13, 図 14 抢よび図 15 に示す結果となった。ただし, 変位とは図 12 中に 示したアクチュエータ先端の変位である.図 13 抢よ び図 14 は, 各印加電圧に扔ける $x$ 方向抢よび $y$ 方向 の時間応答性を示している. 図 15 は, 各印加電圧に

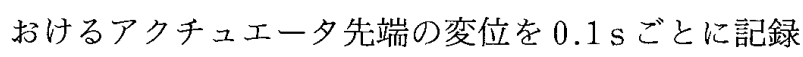
した結果であり,アクチュエータ先端の軌跡を示して いる。なお，図 15 中に表記されている時刻は，各印加 電圧においてアクチュエータの変位が収束した時刻を 示している.

$5 \cdot 2$ 考察 まず,アクチュエータの $x$ 方向の変 位について述心゙る. 図 13 より, 各印加電圧ともに ECF ジェット発生部への電压印加を開始してから $0.3 \mathrm{~s}$ 程度で変位が観測されはじめ, 初期の変位は負 方向であることがわかる. 印加電圧が比較的低い 4.0 $\mathrm{kV}$ および $4.3 \mathrm{kV}$ の場合は, 変位が負方向のままで

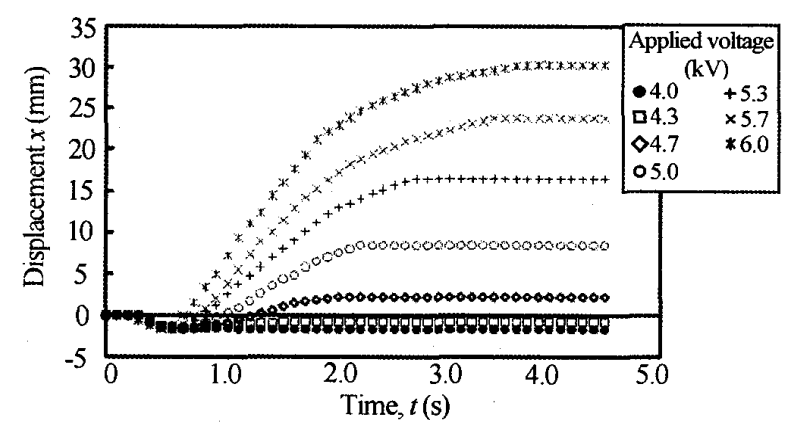

Fig. 13 Response of bending actuator

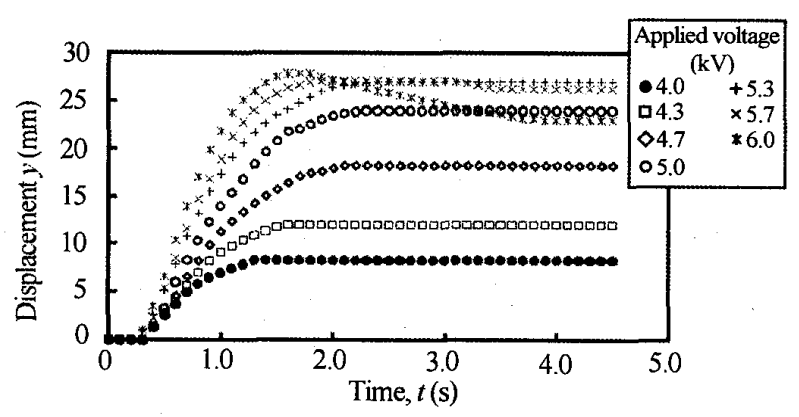

Fig. 14 Response of bending actuator

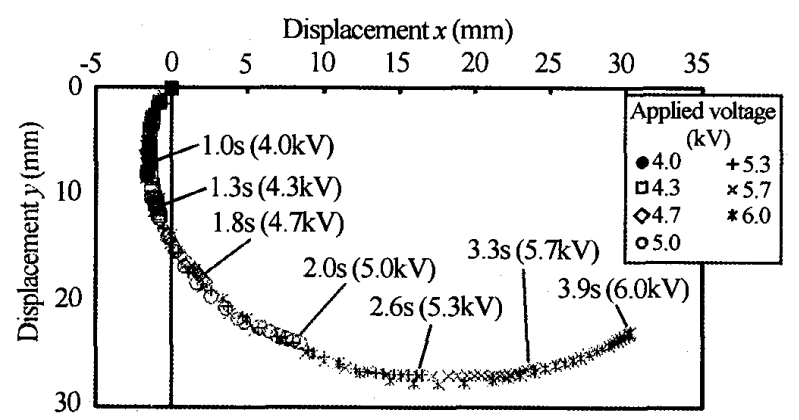

Fig. 15 Characteristics of bending actuator 
あり, $4.7 \mathrm{kV}$ 以上の電圧に扔いては $1.0 \mathrm{~s}$ 付近から正 方向の変位となり, 印加電圧が高い活ど大きな变位を 示している．初期の変位が負である理由としては，ア クチュエータ製作の都合上, 軸方向に強化繊維が配置 されていない側が初期状態において若干収縮している ためである。なお， $6.0 \mathrm{kV}$ を印加した際の $x$ 方向の 立ち上がり時間は $1.96 \mathrm{~s}$ であった。

つぎに, $y$ 方向の変位について述べる。図 14 より, $y$ 方向の変位に関しても $x$ 方向同様, 電圧開始から $0.3 \mathrm{~s}$ 程度から変位が観測されはじめ, 数秒後に一定 の值に収束していることがわかる.この際, $5.3 \mathrm{kV}$ 以下の電圧の場合は最大值に収束しているのに対し， 電圧が比較的高い $5.7 \mathrm{kV}$ および $6.0 \mathrm{kV}$ の場合は最 大值を経た後に一度値が減少し収束することがわか る.これは，図 15 に示すように，アクチュエータ先端 の軌跡が円弧状になっているからである.なお，6.0 $\mathrm{kV}$ を印加した際の $y$ 方向の立ち上がり時間は $0.87 \mathrm{~s}$ であった。

アクチュエータ先端の軌跡に関しては, 図 15 より, 印加電圧が高くなるに従い変位量が大きくなるが, 各 印加電圧における変位は同様な軌跡上に位置すること がわかる。

本実験より，製作した ECF ジェット発生部を用い て,アクチュエータの駆動を確認し, 図 15 より, ECF ジェット発生部への印加電圧を変化させることにより アクチュエータの変位を制御可能であることがわかっ た.

\section{6. ポンプ・タンク一体型液圧駆動}

\section{ロボットフィンガ}

6・1 設計および製作 製作したロボットフィン ガを図 16 に示す.ロボットフィンガは湾曲アクチュ エータ, ECF ジェット発生部および ECF タンクによ り構成され，内部は共有の ECFにより満たされてい る.ロボットフィンガ内への ECF の導入については, 5 章と同様に真空引きを行うことにより達成した。た だし，本実験においてはロボットフィンガ後方に他端 を外部 ECFタンクに浸したゴムチューブを接続し， 真空引きを行った.ロボットフィンガ内を ECFによ り満たした後, 図16に示すバルブを用いてゴムチュ ーブを遮断し, バルブ後方のゴムチューブは切断し た.このため, 5 章における実験と異なりアクチュエ ータ, ECF ジェット発生部䇽よび ECF タンクが一体 となり，全ての流体は密閉されている。また, ECF ジ エット発生部内の各電極対に接続された導線は図 16 に示す ECF タンク後方のシリコーンゴムキャップ内

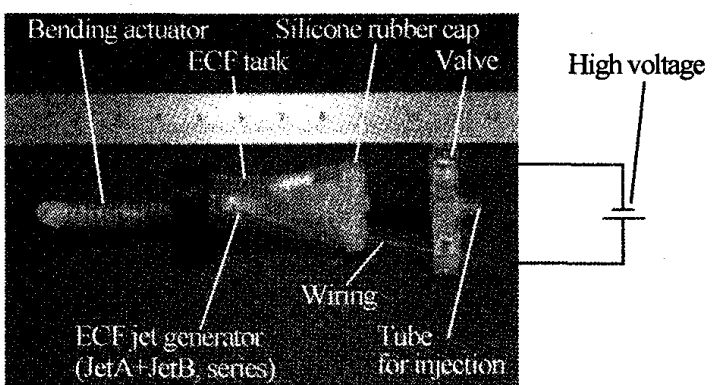

Fig. 16 Photocopy of robot finger

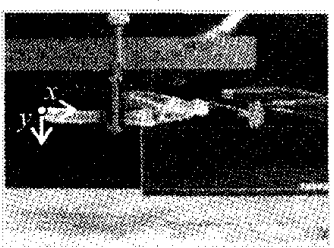

(a) Initial state

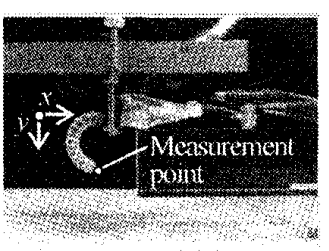

(b) Applied voltage $6.0 \mathrm{kV}$, $t=3.1 \mathrm{~s}$
Fig. 17 Motion of robot finger

を通り外部電源に接続されている，導線をシリコーン ゴムに挿入した後もゴムが弁の役割を果たすため, 内 部の $\mathrm{ECF}$ が漏れることはない。なお, ECF タンクは 膜厚拈よそ $100 \mu \mathrm{m}$ のシリコーンゴム製であり,アク チュエータに比べ十分に大きくロボットフィンガの駆 動に影響はないと考えられる。

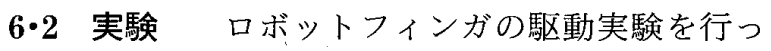
た. 実験結果を図 17 , 図 18, 図 19 および図 20 に示 す.図 17 はロボットフィンガの駆動の様子を, 図 18 および図 19 はロボットフィンガに各印加電圧をステ ップ入力した際の $x$ 方向および $y$ 方向に関する先端 変位の時間応答性を, 図 20 はアクチュエータ先端の 軌跡をそれぞれ示している. なお，本実験での座標系 および図 20 中の時刻は 5 章における実験と同様であ る.

本実験より製作したロボットフィンガの駆動を確認 した.しかし，実験結果を 5 章における実験結果と比 較すると, ロボットフィンガの変位が減少したこと, および図 20 に示すように先端の軌跡にばらつきが生 じたことがわかる。これらは，ECF ジェットによる 発生压力が ECF タンクを収縮させるために使用され たことに起因すると考えられる。なお，アクチュエー 夕および ECF ジェット発生部は 5 章に扔ける実験に 用いたものと同様であるため,アクチュエータおよび $\mathrm{ECF} シ ゙ ェ ッ ト$ 発生部の性能の差による影響はない. 一方，ロボットフィンガの応答性に関しては, $6.0 \mathrm{kV}$ を印加した際に $x$ 方向および $y$ 方向の立ち上がり時 


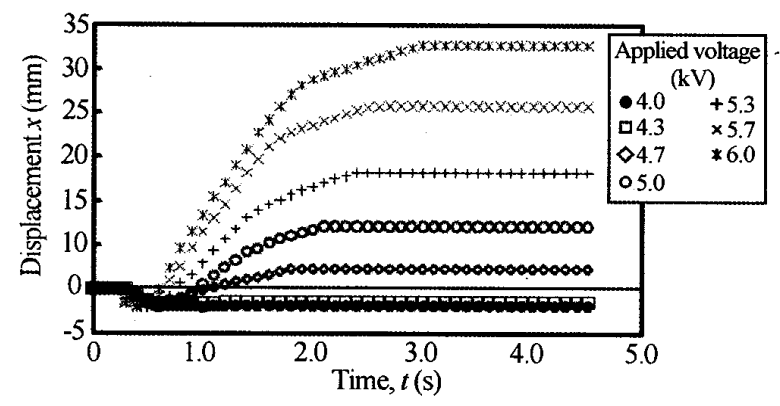

Fig. 18 Response of robot finger

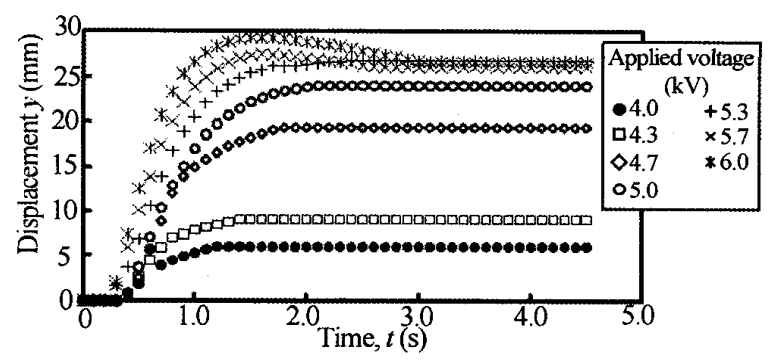

Fig. 19 Response of robot finger

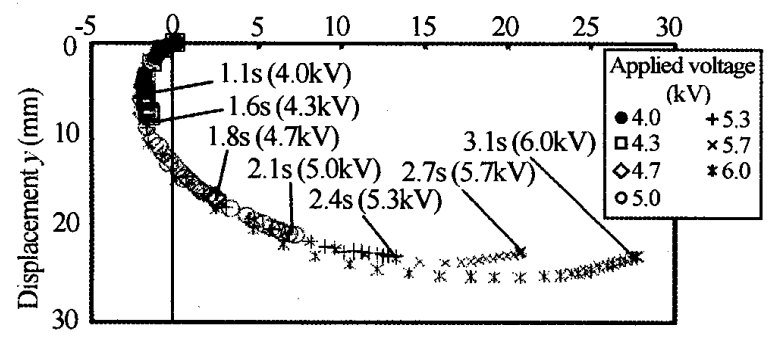

Fig. 20 Characteristics of bending actuator

間はそれぞれ $1.94 \mathrm{~s}$ および $0.68 \mathrm{~s} て ゙ あ り ， 5$ 章におけ る実験よりも早い結果となった。これは，本実験にお いては 5 章における実験とは異なり，ECF ジェット 発生部とアクチュエータの間にゴムチューブが存在し ないため，この部分での圧力損失が無いからであると 考えられる。

\section{7. 結言}

本研究では, ECFを駆動源としポンプおよびタン クが一体となった液圧駆動ロボットフィンガを提案し た。また，ロボットフィンガの圧力源である ECF ジ エット発生部を設計および製作し，特性を評洒した。 この結果, ECF ジェット発生部に関する諸特性が明 らかとなった。

つぎに，製作した ECF ジェット発生部を用いて湾 曲アクチュエータの駆動実験を行った結果, ECF ジ エットによるアクチュエータの駆動を確認し, ECF
ジェット発生部への印加電圧を変化させることにより アクチュエータの変位を制御可能であることがわかつ た.

さらに，上記のアクチュエータおよび ECF ジェッ 卜発生部を用いてポンプ・タンク一体型液生駆動ロボ ツトフィンガを製作し, 駆動実験を行った結果, 提案 通りに駆動することを確認した。

今後は, ECF ジェットの応答性を明らかにすると ともに，上記のロボットフィンガを複数用い, 小型軽 量かつ柔軟な 5 指ロボットハンドの実現を目指す.

\section{文献}

(1) Onishi, M., Odashima, T., Asano, F. and Luo, Z., BioMimetic Control Research Center, and RIKEN, Development of PC-based 3D Dynamic Human Interactive Robot Simulator, IEEE International Symposium on Computational Intelligence in Robotics and Automation, (2003-7), pp. 1213-1218.

(2) Sasaki, D., Noritsugu, T. and Takaiwa, M., Development of Pneumatic Soft Robot Hand for Human Friendly Robot, Joumal of Robotics and Mechatronics, Vol. 15, No. 2 (2003), pp. 164-171.

(3) Yamano, I., Takamuku, S. and Hosoda, K., Development of Underactuated Humanoid Robot Hand for Adaptable Grasp, Proceedings of the Japan Society of Mechanical Engineers, Robotics and Mechatoonics, CD-ROM, No. 1A1-1A11 (2008-6).

(4) Kawanishi, H., Shimonura, H. and Shimizu, Y., Educational-industrial complex development of an anthropomorphic robot hand 'Gifu hand', VSP and Robotics Society of Japan 2001, Advanced Robotics, Vol. 15, No. 3 (2001), pp. 357-363.

(5) Maeno, T., Non-Linear Analysis and Control of Power Ultrasonic Motors, Next-Generation Actuator Leading Breakthroughs, Vol. 4 (2007), pp. 109-112.

(6) Kaminaga, H., Yamamoto, T., Ono, J. and Nakamura, Y., Anthropomorphic Robot Hand with Hydrostatic Actuators, Proceedings of the Robotics Society of Japan, CD-ROM, Vol. 25, No. 1 L 17 (2007-9).

(7) Konishi, S., Kawai, F. and Cusin, P., Thin flexible endeffector using pneumatic balloon actuator, The Journal of Sensors and Actuators A: Physical, Vol. 89, Issues 1-2 (2001), pp. 28-35.

(8) Abe, R., Takemura, K., Yokota, S. and Edamura, K., Concept of a Micro Finger using Electro-conjugate Fluid and Fabrication of a Large Model Prototype, The Journal of Sensors and Actuators A: Physical, Vol. A-136, issue 2 (2007), pp. 629-637.

(9) Takemura, K., Yajima, H., Yokota, S. and Edamura, $\mathrm{K}$., Integration of micro artificial muscle cells using electro-conjugate fluid, The Journal of Sensors and Actuators A: Physical, Vol. 144, Issues 2 (2008), pp. 348-353.

(10) Shinohara, T., Dota, S. and Matsusita, H., Development of a Pneumatic Bending Soft-Actuator and its Application, Transactions of the Japan Society of Mechanical Engineers, Series C, Vol.71, No.711 (2005), pp. 3167-3173. 